\title{
1. Introduction to Populism and Corruption
}

\author{
Jonathan Mendilow
}

\section{INTRODUCTION}

This book seeks to address an imbalance in the consideration of the links between populism and corruption in the academe as well as among the public at large. As both phenomena seemed to spread in the democratic systems of Europe, the USA, and elsewhere, the past three decades have witnessed an increasingly intense academic consideration of corruption and of populism. A voluminous literature also came to focus on the association between them. But whereas students of populism agree that the claim of elite political corruption constitutes a core element in the definition of their subject, only few researchers of corruption have so far reciprocated by studying the effects of populism on the abuse of power. Our goal is to investigate two connected clusters of questions. One is an enigma that was omitted in the study of populism itself: whatever is the meaning of "elite", how do we substantiate or refute the allegation that this group is engaged directly or indirectly in nefarious political activities? The other is the real-world link between populism and corruption: What explains the incongruity of the protest against elite corruption at the core of the populist message and the bleak record of actual corruption of populists in office? Does populist rhetoric merely serve immoral actors to manipulate widespread resentments, win office, and "mask corrupt acts perpetrated by [themselves] and their collaborators" (Kossow, 2019: 1-3)? Such a possibility was already raised by Isaiah Berlin (Berlin et al., 1968: 177) when he considered what he called "false Populism", the employment of populist ideas "for ends other than those which the populists desired." The reference, however, was to specific outliers such as Bonapartism or McCarthyism rather than a sweeping generalization. A possible midrange alternative is that many populists seek to reframe what constitutes corruption to sanction behaviors (including their own) that hitherto would have been understood as illicit.

Because both corruption and populism are contested terms, the understanding of our subject necessitates a brief conceptual clarification. Unless we agree 
on the meaning of the terms we could hardly comment on their intersection. This is especially true because corruption is a noun denoting a specific form of behavior that is counter to established norms. It carries negative connotations of serving individuals or small groups at the expense of the many. Populism, on the other hand, refers to a distinct pattern of anti-establishment ideas, style, or strategies employed to gain or maintain power. In itself, therefore, it carries neither negative nor positive connotations. Nevertheless, a few points of similarity between the two terms stand out. Both were known and employed in what is today referred to as "the West" before the twentieth century. ${ }^{1}$ In the final decades of that century they were equally considered to be relevant mainly outside the world of developed democracies. Massive corruption scandals and the rise of populist parties in Europe in the early 1990s drove home the realization that a more general understanding of the concepts was required, and the efforts to widen the applicability were further enhanced in the new millennium. As far as corruption is concerned, the global economic slowdown of 2007-09 served (to employ Warren Buffett's image) as a tide that receded and exposed those who had swum naked. At roughly the same time, attention was drawn to dramatic problems of non-democratic regimes, such as the accusations of corruption that had become an integral part of "the Arab Spring" (Peleg and Mendilow, 2014). In the case of populism, the surge of populist parties and movements was made evident by the close proximity in time of shocking events in the three oldest democracies: the Brexit referendum, the election of Donald Trump, and Marine Le Pen's advance to the second round of the presidential elections in France. And yet, efforts to broaden the meaning of corruption and of populism were hobbled because both manifested themselves differently according to time, place, and discipline. Irrespective of the fact that most students in the two fields subscribe to dominant definitions, the increased interest served to highlight disagreements as to what each term means. What Moffitt and Tormey (2014: 381) wrote about populism equally applies to corruption: increased interest propelled them to become some of "political science's most contentious issues".

\section{CORRUPTION}

Corruption is by far the older of the two concepts, having been employed already in ancient times. The meaning was not in doubt during most of this history, yet the current contentions are rooted in modern efforts to apply the assumptions underlying it. As Buchan and Hill (2014: 9-45; also Hill, 2013) point out, the oeuvre of Athenian and Roman thinkers contained two divergent meanings. One was the wholesale moral and spiritual decay that indiscriminately infects citizens because of the natural widening gap between empirical realities and the ideals by which they are assessed. This "naturalist" interpreta- 
tion was endorsed in later times by Ibn Khaldun (Hindess, 2012: 4-5) and then by Machiavelli (see among others Burcham, 2012: 53-72; Buchan and Hill, 2014: 68-124). The other meaning was the narrow, legalistic "public office corruption", the abuse of public office for private gain. In medieval thought such behavior was assumed to constitute a violation of the divinely ordained universe, and hence the two meanings tended to merge. They separated once more towards the end of the eighteenth century, most clearly in the work of James Madison and his fellow institution builders. Because their mission was practical and goal-oriented, they abandoned the naturalist tradition to focus on how to ensure that public servants would not violate the boundaries of their office in pursuit of goals that diverge from the "public good".

What is meant by "corruption" did not become the object of academic inquiry in the next two centuries. And yet, the Madisonian system was based on suppositions that came to limit its future applicability even in Western democracies. One was that the boundaries of public positions could be clearly defined. Another was the corollary according to which unambiguous rules of conduct would ensure that officials would not overstep these limits. In periods of rapid technological and social change both assumptions proved problematic. Already in the early 1980s, Skocpol (1982) drew attention to comparative-historical studies demonstrating that even in liberal democracies public officials were able to use state power to redirect society and politics. In recent times this became ever more evident, as challenges and tasks became increasingly fluid and fulfillment of public expectations required growing creativity and expertise (Mendilow and Phélippeau, 2019). What may have delayed further reconsideration was the assumption that democracies are largely immune from serious corruption since the ability of the citizenry to "throw the rascals out" serves as ample deterrent. This same postulation could explain the tendency to view corruption as characteristic of "third world" countries that have not yet embarked on intensive democratization, or where democratic institutions and legal arrangements have been legally installed but actual behaviors still correspond to earlier, non-democratic patterns. As a transitional phenomenon, Samuel Huntington argued in 1968, corruption was especially rampant "during the most intense phase of modernization" (Huntington, 1968/1989: 377). The result was a wide-reaching agreement among Western scholars and policy makers according to which democratization is the assured way to overcome endemic corruption.

It was not long before doubts began to emerge. In the 1970s, high-level corruption roiled the USA (the Watergate scandal). And shortly following the victory of the West over the "corrupt" communist system, Western Europe was shocked by a series of scandals. We need not elaborate, or speculate on the degree to which the wave of revelations reflected moral deterioration, the growth of a news industry hungry for scoops, or the shifting relationships 
between political parties and other social actors (Pujas and Rhodes, 1999). Suffice it to mention a few of the cases that came to light. The most remarkable of these was the immense web of corruption exposed by the so-called "Mani Pulite" ("Clean Hands") investigations into bribery in Milan that in turn exposed a network of corruption involving politicians from all parties and the highest levels. "An entire political class has been put on trial and the political system transformed, largely as a result of public outrage at ... corrupt bureaucrats, businessmen, party officials and members of parliament" (Mény and Rhodes, 1997: 95). In Germany, the long-term Chancellor, Helmut Kohl, was found to have set up a secret slush fund to channel money to the ruling CDU (Christian Democratic Union); in Belgium, inquiries into the AugustaDassault defense contract led to the conviction of former deputy premier and NATO secretary-general, Willy Claus; in Spain, a series of high-profile scandals resulted in several ministerial resignations and the discrediting of the Socialist government of Felipe González. Even in the UK, long seen as free of high-level political corruption, accusations of sleaze in government led to the creation of a Committee on Standards in Public Life. The cumulative result was the debunking of the "democratic immunity theory" and what Kroeze (2016) called "the rediscovery of corruption in Western democracies".

On the other side of the coin, as it were, developments in "third world" countries cast doubts on the idea that democratization is the only route open for new and developing countries (e.g. Theobald and Williams, 2005; Watt et al., 2005). Questions were also raised about the universal applicability of the "public office" approach. As noted, the underlying assumption was that a meaningful distinction could be drawn between the individual and the public. The latter, it was postulated, was the rightful "owner" of the public office. Appropriate as the two suppositions were for governments based on what Weber called "rational-legal authority", it gradually became clear that such theories did not fit "neopatrimonialism" in the various forms that exist in many of the African and Arab Middle East states (Clapham, 1985: 50-54. See also, among others, Pitcher et al., 2009; Mendilow and Peleg, 2014: 1-3). Such regimes, irrespective of their adoption of formal rational-legal codes, were by and large still based on the identification of office and office-holders. Unlike charismatic authority, legitimacy did not spring from the personal qualities of the office-holder but from the concrete social order. As indicated by the image of father and children, the order consists of networks of reciprocities that cement mutual rights and obligations. The automatic identification of such arrangements with corruption simply meant the tacit assumption that they are Western regimes that somehow became perverted. Pitcher et al. (2009), for instance, point to countries like Botswana to illustrate how patrimonialism is compatible with liberal civil rights, and even political competition. Moreover, 
as an ideal type, it can coexist in hybrids that combine the rule of law with formal and informal personalism and other forms of authority.

The dominant concept of corruption is still the one formulated in the context of "development studies". Joseph Nye's (1967) "behavior which deviates from the formal duties of a public role because of private regarding (personal, close family, private clique), pecuniary or status gains" was detached from its third world mooring and abridged. Variations include "abuse of public power for private benefit" (World Bank) and "misuse of entrusted power for private gains" (Transparency International). Such definitions, however, are still tied to the understanding of corruption as a violation of "rational-legal authority". Not only are they limited to Western systems, but they require us to ignore the extent of change that marks our time. My expectation is that in the aftermath of the COVID-19 pandemic, greater attention will be invested in clarifying what is corruption. Here, suffice it to say that the feeling that the term requires reexamination may explain the appearance of numerous alternative definitions, including such that are restricted to the meaning of corruption in democratic systems alone (e.g. Warren, 2004, 2006). Other critics adopted a different strategy. Because definitions of one and the same thing that are offered under similar circumstances cannot be far apart, it is permissible to assume that "we know corruption when we see it" and discuss corruption without the embroilment created by the need to clarify. To take just one example, Bull and Newell (2003: 3) decided to let the writers of their edited volume work with whatever definition "they think [is] more suitable for their areas of study" rather than "tie them down".

This is not the place to criticize such approaches. Nevertheless, in a book on the intersection between corruption and populism we cannot accept the assumption that "corruption" is an empty shell, filled according to what society - or the scholar - regard it to be at the moment. Such an assumption will restrict the relevance and shelf-life of our analysis. It also implicitly accepts the argument proffered by some populists that corruption refers to behaviors that do not accord with the interests or norms of the dominant elite. The definition we found most helpful is extracted from the writings of Edmund Burke (Mendilow, 2014). To lead the prosecution of former Governor General Warren Hastings for his behavior in Bengal, Burke developed an understanding of corruption designed to avoid specific regime forms, but sufficient to diagnose corruption within specific contexts and to warn against its "importation" into England. All societies, he argued, rely on boundaries that separate authority from social and economic power. The degree of overlap between such sources renders the imperative to define borderlines critical, for without it societies fall into chaos. But the boundaries need not be static or legally explicated. They slowly adapt to shifting realities and find expression in the narratives societies create about their past, religion, literature, art, and so on. 
The French Revolution exemplified for Burke the danger of another form of change: the wholesale abrupt removal of arrangements that had "become stale" (that is, failed to acclimate to changed realities). Corruption, according to this understanding, is another form of undermining society but without seeking wholesale change. It is the use of public office to subvert the boundaries separating social and economic power from political authority in order to advance partial benefits - individual, group, or institutional. Irrespective of the fact that no arrangements are permanent, such behaviors emasculate institutional arrangements and long-term social resilience.

\section{POPULISM}

Many of the difficulties that render populism a contested concept stem from a source that reminds one of what ultimately is dogging the concept of corruption. We do not expect individuals or groups to describe themselves as corrupt, and the same applies with only slight differences ${ }^{3}$ to populism nowadays. As Stanley (2008: 100), Moffitt and Tormey (2014: 384), and others pointed out, populism does not have institutional elements indicating common purposes or philosophy of governing; there is no global populist movement or an international one; no key theoreticians or canonical texts, and all icons are of local rather than universal appeal. As with "corruption," the designation is made by "outsiders" based on standards that must be explicated and consistent if the term is to be useful. Such criteria must be wide enough to capture cases other than the specific one observed, but sufficiently wide to limit the group and differentiate it from cases that "don't belong."

A few words about the well-known history (among others, Deiwiks, 2009; Gidron and Bonikowski, 2014) of "populism" may be helpful. Before the mid-1950s, the term was associated with two late nineteenth-century phenomena: the Russian narodniks who held that revolution will derive from the people (narod), and the rural politics of the Populist party in the American mid-West. The earliest effort to identify broader patterns is attributed to Edward Shils (Allcock, 1971: 372-373) in 1954. The term was adopted again at the end of the decade in reference to McCarthyism, and then generalized in Kornhauser's Politics of Mass Society to signify the type of regime that develops where democratic forms of representation are not matched by the rule of law. This both marked and facilitated a shift of attention to Latin America and the new states of Africa and Asia that dominated the field in the following 30 or so years (ibid.: 375-376).

Efforts to come up with a wider understanding of the term did not, however, cease altogether. The 1967 conference held under the chairmanship of Isaiah Berlin is an early illustration. The contributors first examined the Russian and North American variants and then other cases - especially Latin America and 
Asia. The conference ended in an unanimously accepted definition of populist movements (Berlin et al., 1968: 179). Several of the elements included are acceptable today (e.g. the aim of gaining power for the people as a whole). Others seem to be relevant mainly to the cases considered (e.g. the "usual leadership of intellectuals", or the view of the "more archaic section of the people" as repository of virtue). The same applies to the celebrated volume edited by Ionescu and Gellner (1969). Whereas the editors chose not to offer a definition of their own, in his contribution Peter Wils offered more than 20 different characteristics, a far too wide list to differentiate specific cases. Nor did another seminal attempt to widen the applicability of the concept succeed. Margaret Canovan's Populism (1981) differentiated between "rural" and "political" populism, each divided into subcategories, but no clear statement of what is shared by all was offered.

The early 1990s saw a wave of scholarly and popular interest in populism that became a crescendo that is unabated at the time of writing (June/July 2020). ${ }^{4}$ This was not a result of diminished interest elsewhere, but a response to the string of movements and parties labeled populist that changed the political landscape in most European countries. This did not result, however, in any clarification of the concept. If anything, it substantially fragmented and complicated the definitional effort. The difficulty was that the background was not alike, and the various manifestations of populism were dissimilar.

One or two illustrations suffice. Among the new populist parties were those that emerged in many of the Central and East European democracies established at the end of the Cold War. Among the contributing factors mentioned in the literature were the insufficient level of political institutionalization (e.g. Kriesi, 2014), and the inability to foster a perception of procedural fairness (among others, Lind, 2012; Dahlberg et al., 2013). But perhaps the most potent element was what Krastev and Holmes (2018: 118) described as the "pent- up animosity" engendered by the negative "mimesis towards the reform processes launched ... after 1989" and the rejection of the Westernizing Liberal elites that had initiated it (Krastev and Holmes, 2019; for elaboration see Krastev and Holmes, 2020). This cannot apply to Western countries that did not suffer from insufficient institutionalization or the need to imitate anyone. The succession of scandals mentioned in the context of corruption fomented disillusionment with mainstream political parties in Italy and other parts of Western Europe (e.g. Pujas and Rhodes, 1999) including France (Heywood et al., 2002: esp. 185-188), the National Front was established some 20 years earlier (1972) and Poujadism was active in the 1950s. Nor does this explanation (adjusted to circumstances) help throw light on what happened, say, in the Netherlands, or on later phenomena, such as the Greek populism that emerged in reaction to its economic crisis (Pappas, 2014), not to mention Brexit and the election of Trump. 
Parties and political movements are united by political views and the aim to influence or take over all or part of the political power to advance these views. The corollary is that populist movements and parties could vary markedly from one political setting to the other. Not only are their ideologies anchored in the realities of their adherents, but the structures, procedures, role of leadership, and strategies are only meaningful in context. And the generalization is particularly true where the attempt is to mobilize long-lasting social attachments that are anything but an ephemeral "doorstep opinion" (Green et al., 2002: 50). This, of course, does not mean that party creation or change is impossible. What it does mean is that, even in the new post-Cold War democracies, shifts tended to occur within constraining realities that "permitted" the construction of the new formations, as well as their aims, structures, and modus operandi. At the same time, as Canovan (2004: 242) pointed out, the magnitude of the populist wave that swept Europe forced students to view the new entrants as an intellectual challenge and to endeavor to identify the distinctive message and style they share beyond the differences in their composition, strategy, and policy prescriptions or, one should add, the range within which these could shift without leaving altogether the defined group. What emerged reminds one of the dangers that faced the first generation we mentioned. Since efforts to understand the phenomenon were not restricted to any academic field, the results could reflect what the student was looking for. Thus Wils (1969: 166) could describe the situation where "to each his own definition of populism, according to the academic axe he grinds." More colorfully, Berlin could compare the situation to the Cinderella story in which the prince, equipped with the shoe of populism, sought the fitting foot till he found the beautiful owner to marry (Canovan, 1981: 7).

In addition to the differences between populisms that derive from their time and context, the plethora of definitions offered since the early 1990s reflect the discipline of their authors (a partial list will include political science, sociology, cultural studies, political psychology, communications and media studies, economics, and lately also business and linguistics) and the attributes they focus on (style, form of discourse, political strategy, ideology). ${ }^{5}$ This may explain why the survey of literature referred to above found that 57 percent of the journal articles published between 1990 and 2010 could not be coded within any of the categories. The authors avoided definitions altogether, offered definitions that were too vague to allow coding, or dodged the question by focusing on specific settings (Rovira Kaltwasser et al., 2017: 12-13).

As with corruption, there were scholars who concluded that the use of "populism" should be restricted to journalistic purposes (Jensen, 2011: 76; see, among others, also Moffitt and Tormey, 2014: 381; Urpo and Palonen, 2018). ${ }^{6}$ Others rejected attempts at definition, precisely because such definitions assume that populism is a single phenomenon. Concepts cannot be viewed in 
isolation from the circumstances that gave them birth, and shifts in meaning derive from the relationship between them and the "real world". Hence, it was argued, populism should be considered in terms of geographically and temporally determined "waves" (e.g. Houven, 2011). Others were still more adamant. A minimal "one size fits all" definition, it was argued, reduces complexity, fails to explain mass-based parties, and cannot account for the dynamics of particular settings (de la Torre and Mazzoleni, 2019). ${ }^{7}$ Nevertheless, most scholars converged around a widely accepted core definition that could serve as a compromise of sorts between the efforts to broaden the understanding of the subject in specific directions.

The "accommodation" combines negative and positive components. The former refers to the consensus on the need to decouple the concept from attachments to specific class formations or policies, as for instance fiscally irresponsible deficit spending (for early expression see Weyland, 2001: 8; for recent formulation see, e.g. de la Torre, 2018). The positive component refers to traits that may have been proposed earlier but selected because of their existence in all forms of populism and assembled into a clearly expressed "minimal definition." First is that offered by Mudde (2004: 543), which was elaborated by him alone or in partnership with Rovira Kaltwasser. ${ }^{9}$ One of these qualities is that populism is what Freeden called a "thin-centered ideology" (1998): a body of ideas that does not offer solutions to the full gamut of problems confronting society and hence needs to attach itself to "grand ideologies." The concept was originally employed for nationalism and applied to populism by Canovan (2002), but it was Mudde's use that became standard and that explains the diverse forms in which populism is expressed (Freeden himself later argued that it is "emaciatedly thin rather than thin-centered"10). The other positive element is that, regardless of context, structures, and method of operating, all variants of populism constitute a "moralistic imagination of politics, a way of perceiving the political world" (Müller, 2015: 83) based on three essential claims. First, that society is divided between two homogeneous ${ }^{11}$ and antagonistic groups: what Mudde called "pure people" and the "corrupt elite". Second, that the will of the people is identifiable and is represented by the populists. And, third, that the purpose of politics is to express and carry out this will.

This leaves much room for variation, not only owing to the differences between the ideologies to which populisms attach themselves, but because of the breadth of the claims at their core. To take but one example: even though populists of all stripes claim to confront the corrupt elite, this does not tell us much about who the elite is and how it is differentiated from the people. Critics pointed to different results that flow from a "vertical" economic-based standard as against a "horizontal" culturally based criteria (e.g. Laclau, 2005: esp. 40-42; Fraser, 2017; Mudde and Rovira Kaltwasser, 2018). Other possibil- 
ities were also noted. Rodrik (2018), for instance, indicated the turning against external elites in Brussels in the EU or the Chinese that could pose hurdles for international trade, and Müller pointed to Latin American populists, Johnston, Erdoğan, and Trump as populists who directed the anti-elite barbs to foreign or global actors and their representatives. ${ }^{12}$ Such "populist platforms" can adopt economic policies that favor the economic elites and exacerbate inequality, while using inequality to advance their positions as alternatives to business as usual (Müller, 2019: 36).

Populism is still a contested concept. To quote a prominent student, "as soon as scholars are confident that they have encircled it with their definitional snares, it resurfaces in a different form in another corner of the impenetrable jungle of politics" (Weyland, 2017: 49; see also Mudde and Rovira Kaltwasser, 2018: 1669). The range of variations coupled with the plurality of contexts and disciplinary vantage points renders this a sound depiction. And yet, the ability to rely on common denominators that could serve as a point of departure for comparisons across regions and times (Gidron and Bonikowski, 2014) constitutes significant progress. ${ }^{13}$ An interesting demonstration was offered by Rooduijn's (2014) examination of six cases selected from the USA, Europe, and Latin America on the basis of the greatest possible dissimilarities in time, space, and ideology. Only four characteristics were associated with populism in the three continents and periods: the three mentioned above and, as a fourth, the perception of crisis. On a theoretical level, Rooduijn noted, it is reasonable to argue that the proclamation of a crisis is a consequence of the allegation that "the homogeneous people is exploited and betrayed by corrupt elite" (ibid.: 598). The same may apply (cf. Rooduijn, 2019: 365-366) to the frequently associated characteristic of xenophobia and the singling out of "dangerous others"14 or to the mobilization of the followers through direct, active participation (Vitton, 2017).

The growing number of scholars who use the minimal definition as a basis for inferences about "strategic and even ideological behavior of populist movements" (Woods, 2014: 20) and the avalanche of collaborate studies testify to the change in field. An example or two will include the cross-disciplinary analysis of the new crops of parties in Western Europe (e.g. Muro, 2017); the formation of "Team Populism" and its efforts to compare populisms in the USA and Western Europe on the one hand, and Southern Europe and Latin America on the other (Hawkins et al., 2016); ${ }^{15}$ or the publication of Handbooks where scholars from different approaches work in partnership (The Oxford Handbook of Populism in 2017 and the Routledge Handbook of Global Populism in 2018). No less important is a possible agreement about what is not to be included in the category. ${ }^{16}$ To be sure, attempts to nail down a definition from specific disciplinary perspectives will not cease. This, however, does not contradict Mudde's (2017: 41) statement that: "[as] the number of populism 
studies has exploded, the proportion of scholars using relatively similar definitions of populism has increased rather than decreased." At the tail end of the 2010s, we find scholars (Rooduijn, 2019: 363-365) who take this growing definitional agreement as the first among several factors that differentiate the study of populism in the second decade of the twenty-first century from the previous ones. ${ }^{17}$

From our vantage point, what is of equal interest is the mutual recognition of scholars who differ in the subject of their interest, analytical strategies, and levels of analysis so that their approaches are complementary (Hawkins, 2009; Bonikowski and Gidron, 2016). The aim here is not to offer any literature survey but to exemplify the trend. I will therefore mention only several illustrations randomly drawn from the early 2010s and the last years of the same decade. An example of the earlier period is the blend of the conception of populism as a strategy of political mobilization with that of populism as political discourse to explain its capacity to draw "ordinarily marginalized social sectors into publicly visible and contentious political action while articulating an anti-elite, nationalist rhetoric that valorizes ordinary people" (Jensen, 2011: 82; for a more recent combination that rejects the core discussed above, see de la Torre's (2018: 8) definition of populism as a "political discourse and strategies that aim to rupture institutional systems by polarizing society into two antagonistic camps"). Another illustration is the synthesis between the ideological and discursive interpretations to measure populism and examine the literature on parties in Belgium (Pauwels, 2011). Towards the end of the decade we may point to Ostiguy's (2017) adoption of the cultural approach buttressed by the understanding of populism as style, strategy, and ideology; or to Rensmann's (2017: 124) plea for a "cultural turn" in the study of contemporary populism yielding a new framework that would amalgamate the different approaches "to advance a novel cultural perspective and lay out potential lines for future inquiry."

This broad agreement releases us from the need to engage in a definitional effort of the sort we felt necessary with regards to corruption. Undeniably, it is still useful to categorize the approaches to the study of populism. The questions asked, procedures of inquiry, and forms of analysis are likely to diverge according to the different types of research (see the division into empiricist, historical, and symptomatic approaches, Panizza, 2005), the attributes examined (see the division into the structural, economic, politicalinstitutional, and discursive, Hawkins, 2009; Rode and Revuelta, 2014 ${ }^{18}$ ), or dominant approaches in populism research (for the study of populism as strategy, ideology, and discursive style, see e.g. Bonikowski and Gidron, 2016). Nevertheless, because we do not attempt to add to the understanding of the concept or any of its manifestations, we regard the different definitions as focused on coexisting features of the same phenomenon. 


\section{POPULISM AND CORRUPTION}

This leads us back to the question examined in this book. As noted at the beginning of the chapter, irrespective of the large number of scholars who allude to corruption as a key component in the core definition of populism, the actual juncture between the two is among the least studied in the literature. Only few students have ventured beyond the observation that populists see benefit in the claim of elite malfeasance and the factors that influence the strategy's electoral results. We may suffice by mentioning two. Agerberg (2017) points to personal encounters with local services (health care, education) perceived to be impoverished due to corruption as a strong predictor of populist support. The question that obviously comes to mind is whether populists in power can deliver on their electoral promises (Albertazzi and McDonnell, 2015). Curini (2018), on the other hand, examines the use of political corruption as a valence issue in broader national campaigns. In this context he draws attention to the fact that populist parties discard issues that are directed to the benefit of specific segments and focus instead on what is of concern to "the people" as a whole. In consequence, their "trait d'union" is the focus on valence issues, in particularly such that are not policy related. Corruption perfectly fits the bill. Further, "even in societies where politics are perceived to be 'clean', parties can politicize this issue" (ibid.: 161, 11). ${ }^{19}$

This raises a question that is of greater immediate interest to our subject: what populists mean by the term "corruption." Surprisingly, this too failed to receive deserving attention. Referring to the specific type of right-wing populism, Fogel (2018) argues that for this type corruption tends to be personified. It is not associated with any form of behavior but with an elite or a center-left politician who "becomes the symbol of all that is corrupt and wrong." Likewise, anti-corruption takes the individualized form of "kick the rascals out" while ignoring the structural incentives that produce systemic corruption. This, "ironically, empowers corrupt self-serving leaders like Donald Trump or Silvio Berlusconi." An acute recent and more general contribution (Boatright, 2020) points to the lack of universally accepted criteria for what corruption means that enables populist use of the term to frame a public view of policies, office-holders, or even entire groups. In such usage, the accusation is unattached to the criminal sense of the term. In fact, to fulfill its function, populist "corruption talk" must avoid rigorous definitions altogether. The power of such rhetoric (Boatright and McGrath, 2020) does not derive from the actual content of the language used but from its normative associations.

Among the works that address the impact of corruption scandals on populism or vice versa, only two should be mentioned. Against the background of the corruption scandals that had rocked Western Europe in the early 1990s, 
and especially Italy, Fieschi and Haywood (2004) point to two distinct types of populist reaction. The "traditional alienated" kind is led by anti-intellectual strongmen with direct links to the political Right. "Entrepreneurial populism," in contrast, combines cynicism with basic trust in democracy. The appeal of leaders like Berlusconi was based on their personal achievements, rather than integrity. Representing the "endemic corruption of all mainstream politicians" (ibid.: 303), they promise to "beat the politicians in their own game" and elicit the faith that the benefits will "trickle down". Trust was thereby "placed in an untrustworthy individual in order to play a system whose institutions one does not trust but whose ideals and intentions are still trusted" (ibid.: 304). The impact of populism as a set of ideas on corruption was less directly discussed by Urbinati (2017, see also 2019, 1998). Populism, she argues, reflects the decline of universalist ideas of human freedom and the political parties promoting it. The relativism of "our people first" and the use of political power to serve the interests of a segment of the population (the "people") leads to the exaltation of the leader on the one hand, and corruption on the other.

Among the scholars who offered less elaborated comments on the subject, one (Kossow, 2019) has been mentioned at the beginning of this chapter. Another is Müller (2016: 46-49). The former argues that populist rhetoric is simply a ruse used by corrupt actors to carry out their designs; the latter suggests that the connection between populism and corruption is the product of an ideological premise. The exchange of favors (including "discriminatory legalism") by populists in return for political support springs from the view that only some citizens (i.e. the supporters) are the "true people". These deserve the support, legal or not, of what is rightfully their state. The others are the corrupt elites and their cronies who should be treated harshly. Such a view explains why such parties as the Lega Nord, or Haider's Freedom Party, though far more corrupt than the traditional elites they had criticized, did not pay any electoral price, while Erdoğan remains untouched by corruption scandals. In brief, the perception among supporters is that corruption and cronyism are not genuine problems as long as they look like measures pursued for the benefit of the moral hardworking "us" rather than the immoral or even foreign "them", (ibid.: 47-48). ${ }^{20}$

What may make the paucity of studies about our subject understandable is the fact that the behaviors under consideration are context dependent, while the widespread assumption is that what motivates them is simply greed. Should we adopt such a view, there is no need to offer any further comments on the crossroads we are examining. Several classifications of the "how" and "where," and even "why" of corruption already exist. The World Bank (World Bank Poverty Reduction and Economic Management Network, 1997: 12) contends that "abuse of public office for private gain" could include bribery, theft, political and bureaucratic corruption, isolated corruption, systemic cor- 
ruption, and private sector corruption. The World Bank also offers a model that seeks to capture the dynamics of public sector corruption as a function of the size of the gains ("rents") of corruption, the discretion, and the accountability of public officials. Susan Rose-Ackerman and Bonnie J. Palifka (2016: 8-9) differentiate between bribery, extortion, exchange of favors, nepotism, cronyism, judicial fraud, accounting fraud, public service fraud, embezzlement, kleptocracy, influence peddling, and conflict of interest. The incentives and consequences of corruption are categorized as well, with corruption occurring "at the intersection of situation-specific incentives, society-wider institutions, and personal ethics" (ibid.: 29; see also diagram 1.8, p. 28). And Matthew Page (2018) offers a taxonomy that conflates the "how" and "where" of corruption in Nigeria. Included are 28 different tactics, grouped into eight behavioral categories that cut across 20 sectors, one of which is the political and institutional. This seems overly specific. One wonders whether the selling of membership cards by party officials who pocket the returns is a common form of political corruption in the West, or whether the distinction between the particular economic sectors where corruption could occur - petroleum, agriculture, infrastructure, power, finance, and environment - is useful elsewhere. Nevertheless, the blending of tactics, types of behavior, and sectors is a helpful tool that could be adopted to the analysis of other counties, including ones that are less corruption infested than Nigeria.

We do not purport to add anything to such classifications. The attempt is rather to mention briefly several nonexclusive situations involving the way supporters perceive the involvement of their populist leaders and corruption. Such situations could obviously tell us something about the incentives and justifications (cynical or otherwise) employed by the leaders concerned, and hence also suggest indirectly the reasons why the confluence of populism and corruption is so common.

Before we embark on this analysis, it is worth reminding readers of the definition of corruption used in this book. As noted earlier, an advantage of Burke's concept of corruption is that it does not require the use of criteria fitting "rational-legal authority." A related benefit is that the definition does not rest on any specific laws that define corruption. Such laws could themselves be the outcome of corruption or claimed by populists to reflect the interests of the "corrupt elite." No less relevant, especially in situations of significant political change (e.g. the appearance of populist challenges to liberal democracies), laws need not reflect societal understanding of what the concept means. A helpful color scheme was suggested by Arnold Heidenheimer (1989: 149-164) to denote the association between mass public opinion about what is corrupt and the legal definition of the term. Behavior that is considered as corrupt by mass opinion and is defined as such by the law is indicated by the color black. Gray implies an ambiguous situation where the public is divided. 
Many agree with the standards identified by the law, but a substantial part of the public hold these standards as mere formalities and absolve the behavior that they identify as corrupt. Finally, white signifies the agreement of both elites and broad publics that a behavior, despite being formally defined as corrupt, is not. In a discussion of corruption and populism, with its anti-elite and anti-establishment positions, the question is what is "black" or "gray" in the color scheme.

One possible meeting point between populism and corruption already mentioned is where corrupt politicians take advantage of their position to make illicit profits at the expense of the public at large or of specific victims (e.g. blackmail or shakedown). I will use the term "opportunistic corruption" to denote the exploitation of circumstances that "permit" illegal gain by populist leaders. Such activity usually takes place away from the limelight because it falls within the boundaries of what Heidenheimer signified by black. The unjustifiable attempt to serve selfish interests can hardly be defended. Even should supporters regard it as "not too serious," the behavior tends to erode authority. Whether it is bribery, embezzlement, extortion, or any other tactic listed by the classifications mentioned above, it could take place at all levels of authority. Nevertheless, one assumes that in its "pure form" it is rare in developed democracies, at least at the topmost positions.

What is more likely to involve high positions of power could be termed "compensatory corruption." By this I mean where corruption, whether performed in broad daylight or exposed by legal authorities or the media, is "forgiven" by followers as triviality or even considered by them as a reward for achievements gained on their behalf. An illustration is the reaction to the indictment of Israel's Prime Minister, Benyamin Netanyahu, for corruption, fraud, and breach of trust. The immediate response of supporters was a mass protest rally that opened with the complaint voiced by the mistress of the ceremony: "the state of Israel against Benjamin Netanyahu. Never has there been a more abominable, filthier, more chilling sentence. How ungrateful!" (Ha'aretz, November 26, 2019). In his own televised retort, Netanyahu described himself as having "sacrificing my life for you, the people of Israel" and promised "to implement my right, my duty and my mission to continue ... to lead Israel to great achievements" (Ha'aretz, January 1, 2020). In the parliamentary elections that resulted from the inability to form a government coalition in earlier rounds, Netanyahu's party actually increased its share, and, at the moment of writing (June/July 2020), he is the longest serving Israeli Prime Minister and the first to stand trial while in office. Both testify to the widespread feeling among supporters that the alleged offenses pale in comparison with his accomplishments and the needs of the nation. Significantly, mass protests against both his performance and alleged corruption broke out with the outbreak in early July of a second COVID-19 wave, the threat of its spiraling 
out of control, and the reversal of early government success in confronting the pandemic.

A different situation is where corrupt behavior is perceived by followers to advance collective rather than private interests, and hence as a service to the supporters rather than a reward. What could be called "group oriented corruption" is especially likely to meet overt or covert consent when confronting rival political forces. Populism involves a worldview based on antagonism, the conflict between the people and the corrupt elite (regardless of whether the conflict is horizontal/vertical, ethnic group/minorities, or insiders/global "elites"). The perception of high stakes could spread to members of anti-populist parties who feel that to win the crucial contest they must beat populists at their own game. The consequence in such a case could be legitimization of corruption and the general weakening of the rule of law.

An illustration is offered by Sierakowski (2019), in his analysis of what took place in Poland. Law and Justice (PiS) chairman Jaroslav Kaczynski is quoted as assessing that the members will accept institutional corruption "that benefits the party, but not corruption that benefits the individual." Research conducted (with Przemyslaw Sadura) into the attitudes of party members prior to the October 2019 parliamentary election shows that the assessment was correct. On the question "should politicians ... be forgiven for engaging in corruption to some degree?" the representative response differentiated between corruption aiming at furthering group interest and behaviors intended to promote "individual material benefit." The latter should terminate the politician's career; yet members were inclined to accept corruption "for the party, for the greater good." The conclusion was that "acts that voters would regard as unacceptable in most other domains of life suddenly become virtuous in a partisan political contest."

A variation on the theme is "defensive corruption." By this I mean the situation where such lines as the PiS voters attempted to draw are even less clear in two ways. One is that the behavior is "pre-emptive." The motivation is not to avoid the disadvantages of confronting dishonest rivals, but to prevent the possibility of future defeat by parties that play according to the rules. The second is the blurring of the difference between the individual/s and the political collective. What is broadly considered as corruption is performed to ensure the electoral win of an identifiable leader or leaders, or the extension of their authority, rather than the immediate benefit of a party or a movement. The similarity between "group oriented corruption" and "defensive corruption" owes itself to the unclear distinction between the leadership and the party or movement itself where future victory is in danger or where present attempts to expand the authority of "the people" meets strenuous resistance.

An example that leads back to Netanyahu concerns the nature of his indictments. Of the three cases brought against him, one involves the alleged 
acceptance of goods worth some NIS 700,000 (at the time of writing, over US $\$ 200,000$ ) as "a token of friendship" by a specific person whose interests (so claims the Prime Minister) did not receive preferential treatment. The other two indictments concern alleged attempts to bribe controlling shareholders of Israeli media groups in return for improved coverage. Unlike the first charge, the two media-related ones raise eyebrows. Words of praise and the image of success are, of course, a source of gratification. However, as sole motivation this begs the question whether the risk for a long serving Prime Minister, considered by his followers to be a "magician," is not excessive. For obvious reasons, no proof could be adduced in support of the premise that the answer to the cost/benefit riddle lies in the context. Moreover, the rejoinder may also explain the supporters' acceptance of the definition of the indictments as a "witch hunt," irrespective of the fact that they were served by an Attorney General who was nominated by Netanyahu himself. Israel features a parliamentary system where seats are allocated on a nationwide proportional basis, and the threshold for representation is 3.25 percent. In consequence, no party had ever succeeded in ruling alone. After the collapse (1977) of the Labor-led dominant party system, all governments were either "national coalitions" between the main contestants or narrow, fructuous partnerships between one of the main rivals and several small parties. The pattern became ever more prominent against the process of structural polarization in which a disunited center-right and a disunited center-left became equal in size. This culminated in the elections of April 2019, when, for the first time, neither side was able to present a coalition. What followed were two rounds of legislative elections in which both sides failed to break the stalemate. A further round became unnecessary, however, once the COVID-19 pandemic forced the main rivals into a national unity government. Well before this unprecedented situation developed, it became clear that the ability of "the people" to ensure victory hinged on a relatively small number of votes, and that the perception of success in office acquired the utmost importance.

An electoral system such as that of Israel is not the only possible source of limits that check the power of populists and stimulate "defensive corruption." Majoritarian elections at both the US federal and state levels amplify Trump's capability to express views and "truths" intended to enhance his image. Yet the constitutional order sets limits to his ability, and that of his supporters, to pursue their agenda, and jeopardizes their capacity to ensure continued electoral success. The USA is a vast non-centralized entity, where staggered elections take place in different settings. The division of political authority in each, and at the federal level (the checks and balances between the two houses of Congress, the judiciary, and the executive) results in a hybrid "distinct from what might emerge in other national contexts" (Pierson, 2017: S106). No less important is the composition of the Republican Party. Trump's election con- 
cluded a process that had begun in previous decades, in which a "plutocratic populist" party gradually emerged, bringing together organized monetary interests of a small minority on the one hand, and the mass outrage of less affluent and less educated publics on the other (Hacker and Pierson, 2020). The latter's lack of organization may explain how Trump became their champion and center of political identity. Nevertheless, the tension between the interests of the two pillars of the party forced it to advance policies that would benefit its affluent supporters alongside symbolic matters such as immigration, cultural, and racial umbrages that could shift attention to issues of identity designed to attract the less affluent. The strategy, already practiced by Newt Gingrich, was perfected by Trump, whose use of social media (especially Twitter) allowed daily contact with his core supporters (Mendilow, 2018; Smith and Hanley, 2018). But it was not designed to expand the narrow Republican coalition, and it deepened interparty divides. It thereby threatened to energize voters who resisted such appeals. This situation worsened following the outbreak of the COVID-19 pandemic and eruption of protest against police maltreatment of racial minorities. Yet the inherent vulnerability was clear from the start, and may help clarify the alleged effort to force Ukraine to deliver "dirt" on the person who was suspected (correctly, as it turned out) to lead the out-of-office party. It likewise explains the president's "exoneration" not merely by the "base" but also legislators who became dependent on the support of the core and its ostensible leader to ensure their continued ability to serve the interests of a relatively small minority.

At the polar opposite of opportunistic corruption are behaviors that are considered by widespread opinion as corrupt, even though they are not defined as such by any laws. Was Trump's alleged behavior in the Ukraine scandal criminal? An attempt to examine whether it involved bribery, extortion, electoral finance violation, or obstruction of justice (Millhiser, 2019) requires a consideration of the connection between legal procedures and actual behavior. Suffice it to note that the law, its interpretation, and application are not objective and immutable. Laws are produced by the politically powerful, and this is especially true of corruption, where the issue is the limits of authority. A concept that illustrates the problems that may ensue is of "legal corruption" (Kaufmann and Vicente, 2011). The seemingly paradoxical combination signifies the situation where legal procedures - or the law itself - are manipulated to shield authority holders bent on making profit from leasing public resources to economic interests, or enabling such interests to legislate corrupt laws themselves while protecting them from public reaction and legal consequences. The concept does not apply only to less affluent countries. Kaufmann and Vicente found that many G7 (Group of Seven) and OECD (Organisation for Economic Co-operation and Development) members present challenging cases (ibid.: 216) and, in fact, one wonders whether the borderline between 
this and lobbyism - or even "business friendly" policy - is clearly demarcated. The assumption that corruption is simply what the law defines it to be seems too simplistic.

For Burke, what constitutes corruption is determined by social conceptions, religious beliefs, historical experiences and political culture, all of which undergo gradual and constant change. Laws may add clarity, but to accomplish this they must adjust to the change. This, however, assumes relative stability. The law may be a "lagging indicator", but especially in times of rapid change, the normative foundations, as well as the interpretations of past experiences and future directed task expectations at their basis might shift faster than usual and be subject to societal disputations. In such times the answer to the question of what is corrupt may well hinge on who holds authority.

In the context of the discussion of populism and corruption two basic situations warrant attention. One is the exploitation of opportunities that lead to actions on which the law is silent but are perceived by large segments of the public as corrupt. An example is the presence of companies linked to the Kushner (Trump's son-in-law) family, clients of Trump-connected lobbyists, and large Trump donors among the early and largest recipients of the "Coronavirus loans" that were offered as relief to small businesses and that were soon exhausted (Mellman and Eisen, 2020). A different kind of behavior was the application of blanket ethics waivers to potential administration conflicts of interests connected to such loans. The words of one expert could have been written to illustrate "legal corruption": "the idea that the small business administration can, without any review or publicity, secretly let all of its employees arrange loans for their family members or associates is outrageous" (quoted in O'Connell and Gregg, 2020). In both cases the conduct was kept in the dark and resembles what we referred to as "opportunistic corruption" except that it is not illegal. The same applies to its reception in public, although one would assume that negative reactions may be blunted by the absence of explicit legal prohibitions.

A different form of "legal corruption" is the flouting of norms and standards in broad daylight by populists seeking to advertise their anti-establishment positions. Because this volume contains a chapter on the subject and because it is so prominent, Trump will be used again as an illustration. In the words of Frank Vogl, co-founder of Transparency International, "in another era, just one or two of the cases would have been sufficient to do enormous damage to a President of the United States. But in the Trump era, the scandals come so frequently and fast that nothing seems to stick" (Vogl, 2020). The absence of a huge number of lawsuits is not necessarily a reflection of "compensatory corruption," or the complexities of launching complaints against a sitting president, but of the fact that most of the cases involved are not explicitly defined by law as corruption. Vogl's subtitle, "from the Art of the Deal to the Art of 
Undermining," suggests a deliberate strategy to undercut accepted norms and practices that were enshrined by past elites.

Whether the plethora of what is considered corruption by much of the public is a reflection of Trump's unusual personality or a game plan (or, perhaps, a mixture of both) is a question that is impossible to answer at the moment. From our point of view, however, the answer is not essential. The number of cases is so large that the particulars of very few register in the mind, or even are elaborated by the media. A parallel is the amazing number of untruths proffered by the president (those who care to count reached the tens of thousands!). The overall effect is the weakening of accepted norms (and the notion that there is no such thing as "truth") while contributing to the perception of President Trump among his "base" as "our man."

If this analysis is correct, we can regard the phenomenon in terms of the "low culture" considered by Ostiguy $(2009,2017)$ as characteristic of populist leaders, and applied to Trump by Ostiguy and Roberts (2016). By "low culture" is meant a way of relating to people that puts the emphasis on performance and the exhibition of qualities such as the rudimentary level of language, folksy expressions, vulgar gestures, and the display of popular tastes. The content loses importance. What takes its place are the words of the "strong male leader," who "shoots from the hip," and "tells it like it is." Though the source is "the people," the authority sought is personal: an attribute of "politicians 'with balls' who are coarse, uninhibited, culturally plebeian (even if materially wealthy) ... and anchored in the "here and now" (ibid.: 32). Such authority involves the rejection of institutionally mediated authority, rules, and procedures that legitimate the authority of the "culturally High." Thus, populist leaders operate as forces of "creative destruction" that knock down traditional political norms and "restructure sociopolitical space around a different - and often highly polarizing - competitive axis" (ibid.: 26). From the perspective of this book the example of Trump is of a scale that is truly exceptional. This refers not merely to the various forms of corruption and reactions they elicited, but to the interconnection between them. But then, in a play on the famous Chinese curse, "we live in interesting times."

\section{THE STRUCTURE OF THE BOOK}

The chapters examining these subjects fall into three parts. The first focuses on several questions that help explain the intersection of populism and corruption. In Chapter 2, "Populism and the Corruption of Pluralist Governance Structures," Frank Louis Rusciano examines the "built in" association between the claims underlying populism and corruption. In his Preface to Democratic Theory, Robert Dahl raises criticisms of the populist model. The chapter generalizes these and applies them to the effect of populism on the structures of plu- 
ralism through different levels, reaching their apex in the interaction between what Boudon calls "axiomatic rules" (or the "democratic creed" according to Dahl) and "apparent behavior" (or majority opinions). Citizen attitudes within this structure form a feedback for elites, who adjust the behavioral structure according to changes in opinion. The chapter analyzes what occurs when the "democratic creed" is replaced by the populist principles that divide society into the "camps" of friends and enemies and allow "states of exception" that permit leaders to operate outside institutional structures.

Chapter 3, "Corrupt Elites, Pure People and Double Standards? Attitudes of Central European Populist and Mainstream Political Party Sympathisers to Systemic and Individual Corruption," reverses the vantage point. Roman Chytilek inquires into the extent to which voters share the claims that lie at the core of the populist political project, especially the division between the two homogeneous groups of corrupt elites and pure people. As the previous chapter illustrates, the comparison between the attitudes of populist and non-populist voters may well explain the manner in which they perceive elite-level corruption. To date such a project has engaged very few scholars and the results paint an ambivalent picture. Some of the students identify significant differences between the populist and other voters, with the former tending towards the belief that populist discourse is a pertinent description of current affairs. Other scholars surprisingly show that "populist attitudes" are distributed among voters of all parties. The chapter explores the issue by an examination of voter attitudes in Central and Eastern Europe. It inquires whether the distinction between individual and elite corruption explains electoral populist success while avoiding electoral penalties for acts of corruption in the in-between periods.

The second part of the book examines a range of specific cases: populist parties in office and in opposition, "right-wing" and "left-wing" populist regimes, and yet another category marked by the process rather than the populist parties' hold on power or their position on the left-right continuum. A short explanation is in order. One of the issues raised by critics of the core definition discussed above relates to its dichotomous distinction between populist and non-populist actors. However, the issue is not the "degree" of populism but the underlying assumption of unitary entities. A party led by populist figures could include leaders who are not of the same bent. The same may apply to the institutions of governance. These may raise resistance that will hamper even the efforts of united ruling parties to change them, and this is even more so where the parties themselves are not cohesive. Such situations, as discussed in the cases of the USA and Israel, suggest the need for nuance and the consideration of politics as an ongoing process of change. From our viewpoint they also merit special interest. We shall try to show that they are particularly prone to corruption and attempts to undermine the rule of law, on the one hand. On 
the other, they pose dangers to populist leaders as exemplified by Trump's impeachment and Netanyahu's indictments.

The discussion of examples begins in two cases mentioned earlier, of the USA under Trump and Israel under Netanyahu. Olivia Newman's "One Man's Swamp" (Chapter 4) examines the former. As a candidate, Donald Trump ran a populist, anti-corruption campaign, promising "to drain the swamp." Yet, as noted, his presidency has been riddled with credible claims of corruption. The chapter looks at the ways in which anti-corruption political rhetoric provides cover for corrupt governance. Specifically, Trump has been able to exploit widespread cynicism towards the political process and mistrust in government to advance a "deep state" conspiracy theory that framed his nepotism, acts of political retribution, and self-dealing as "defensive corruption", protecting the people from nefarious elites. Similarly, he has capitalized on the rise of identity politics and hyper-partisanship to rally his supporters around "group oriented corruption" that justifies electoral interference by promising to protect the "real" people from various threats, including undocumented immigrants and "far-left" Democrats. By pitting himself and his voters against both elites and various outgroups in society, Trump has been able to engage in "opportunistic corruption" in plain sight, with the blessing of his voters, who saw the president's successes as trickling down to them.

The Israeli case is explored in Chapter 5 on neo-liberal populism and clientelism. Ina Kubbe and Edna Harel-Fisher discuss current developments that facilitate the examination not merely of the types of corruption involved but also of the mechanisms to which they are connected. Populists often contravene the law to gain and maintain power as well as enrich themselves and their supporters. At the same time, they tend to roll back anti-corruption laws, delegitimize the fight against corruption, and openly violate ethical standards of public life, what has been referred to as "legal corruption." Current incidents in the country enable the writers to examine the types of corruption involved and the specific forms they take as well as their overall effects on the party system. As in the case of the Polish PiS, the adoption of populist components could well lead to forms of corruption, especially various types of clientelism and "voter construction" (the arrangement of party lists to fit the requirements of specific voters who would cast ballots in return for actual or promised benefits). This form of bribery was used in the Likud internal elections, and later spread to other parties to present new formations as the populist components are added. The chapter examines the assumption that the spread of such forms of corruption across the political system points to the emergence of a new one that has inner connections to previous trends of neo-liberal political corruption.

The case of Brazil is examined in Elizangela Valarini and Maria Eugenia Trombini's chapter on "populist grammar" and the interconnection between it and corruption. Irrespective of the attention received by the "Carwash 
Operation", one of its chapters remains understudied: the corrupt structure uncovered in the state of Rio de Janeiro. The former governor, Sérgio Cabral Filho, was found guilty of diverting some $\$ 4$ million from public budgets to his own account in a scheme that involved a bribe rate of 5 percent of all administrative contracts between the state administration and private companies. Resorting to a populist rhetoric, his defense was that all elites are corrupt. As the representative of the "pure" people, it was his function to ensure that their interests would be served. To do so, he ensured the best price and, in a combination of "compensatory corruption" and "group oriented corruption", deposited the kickback in his account because no one else could have ensured that it would return to the people. Filho served from 2007 to 2014, resigning before the end of his second term. The uncovering of the corruption scheme resulted in large-scale discontentment and an anti-establishment sentiment among the electorate. This could explain the election of his successor, former judge, Wilson Witzel: a political outsider who has already declared his intention of running for president in 2022 and who shares with current president, Jair Bolsonaro, the use of populist discourse. The chapter raises the question of the populist grammar that has been used by the main actors practicing, labeling, and engaging in corruption. How did the scandal of the Carioca Carwash surface, and what does it say about populist discourse during and after the investigation? An examination of the criminal cases on which Sérgio Cabral was charged aims to highlight the rationale for engaging in corruption on the one hand and prosecuting them on the other. What are the reputational gains and losses each narrative yields to the actors participating in the scandals? What is the interplay between corruption and populism?

The populism-corruption nexus in post-communist Europe is explored in Chapter 7, by Michael Shafir. In "Corruption and Populism in East-Central Post-Communist Europe: The Egg, the Hen, and the Omelet," he raises the question whether corruption produces populism or populism induces corruption. Are the two phenomena "mutually constitutive" (Friedrich Kratochwil) or can they exist separately, ignoring one another? Posing the question is tantamount to repeating the old interrogation about the hen and the egg while ignoring the social omelet that both produce. Opting for the opposite perspective, the chapter focuses on the post-communist East-Central European turmoil of the last decade and analyzes to what extent the events presented were influenced by the neo-liberal world which the former European communist countries became part of after 1989. Following a detailed examination of Slovakia and the Czech Republic, the chapter proceeds to examine what they share and in what way they differ from the two other members of the Visegrád Four, Hungary and Poland. The two became known as the East European center of illiberalism, where anti-elitism (directed mainly at the past) intertwines with a powerful presence of ethno-centrism. 
Chapter 8 moves the scene to Mexico and to "left-wing" populism. An assertion made on behalf of such populism is that only it "provides the adequate strategy to recover and deepen the ideals of equality ... that are the constitutive of a democracy" (Mouffe, 2018: 13). Irma Méndez de Hoyos, Tomislav Lendo, and Ulises Flores Llanos's chapter on corruption and populism in Mexico probes this claim. Their inquiry focuses on the question whether Andrés Manuel López Obrador (AMLO) adopted a different approach and practice than his right-wing predecessors in all that concerns corruption. AMLO took office following a campaign that emphasized the fight against corruption and the need to dismantle mafias inserted in public institutions. As a "left-wing populist," the "thick ideology" he presented was significantly different from that of the "right-wing" populists of Europe and the USA, but in common with the former presidents of Bolivia and Venezuela, as well as President Moreno of Ecuador. After a year in office it is worth inquiring to what extent is AMLO's call against corruption more than a moral discourse directed against political and economic elites. Does the administration engage in a real attempt to clean the government, or is it in fact a case of ideological and political revenge? The chapter presents a brief review of the perception of corruption in Mexico in recent years, followed by an analysis of AMLO's anti-corruption stance as presented in his campaign and first year in office. The authors then inquire whether his behavior in office promise the construction and/or strengthening of institutions that would free the Mexican political system from the scourge, or simply a continuation under a new guise of the practices he promised to eradicate.

The final chapter in the second part of the book departs from the examination of the connections between populism and corruption in systems governed by populists to inquire whether similar patterns apply to populist parties and movements in opposition. In "Populist Opposition in France: Rhetoric vs. Practical Constraints," Éric Phélippeau focuses on the populist opposition, with particular attention to the effort of the Front national (FN) to attract votes by claiming to speak on behalf of the "people." Along with "insubordinate France," the party is inclined to denounce opponents as members of the elite, and the "establishment" as corrupt institutions dominated by it. The two main populist parties have a few representatives in the European Parliament, the Assembly and the Senate, and they head only few municipalities. Nevertheless, because they participate in electoral competitions they are required to disclose their financial accounts. It is therefore possible to compare their political practices with their declared positions on public integrity. A critical review of their public accounts reveals the existence of various financial problems. Ongoing court cases suggest that, despite their self-presentation as political "white knights," they are no less vulnerable to the temptation to test the legal limits of political financing, at the risk of resorting to criminal and corrupt political 
practices. This is particularly true of group-oriented, but also opportunistic corruption. The chapter provides explanations for these abuses.

The third part of the book considers another neglected question: how do we substantiate or falsify claims made by populists concerning elite unity and corruption networks. Especially since some of the previous chapters touched on cases where such claims had tangible bases, it is important to avoid pre-judgments. After all, the two-way street linking perceptions and behaviors plays a central part in our endeavor to shed additional light on the mutual effects of populism and corruption in democratic settings. Two chapters are included in this part. In "Who Pays for Populism?" Robert G. Boatright offers an empirical examination of the argument of populist candidates that they seek to counter a corrupt, entrenched political elite and to speak on behalf of the people. Such an argument would imply that populist candidates draw their financial support from different sources than do more conventional candidates. Was this the case in Donald Trump's 2016 presidential campaign? Were his principal supporters different in noteworthy ways from the main supporters of Democratic candidates, or of other Republican candidates? And what were the effects of changes in US campaign finance laws and practices on the Trump campaign's fundraising?

The final chapter closes the discussion offered in this book with the more general question of "How to Examine Populist Claims." Rodrigo Rossi Horochovski, Wagner Pralon Mancuso, and Ivan Jairo Junckes look at the possible contribution of social network analysis (SNA) to the examination of populist claims. The case selected is of Jair Bolsonaro's assertion that he is a vaccine against the traditional politics ills, and his promise to save the people from corruption. In the first year of his term, evidence emerges that his inner circle is tied to networks of corruption. The chapter shows how SNA can help throw light on such a phenomenon, through the identification of networks of political finance that are interconnected to political-corporate corruption networks. The main objective is to demonstrate the potential of the method to identify power elites, their relations and reciprocal ties. The chapter argues that these networks are maintained or even strengthened when populist groups reach state positions with anti-corruption, anti-elite, and anti-politics positions.

\section{NOTES}

1. The American roots were already explored in Hofstadter's "North America" (1969). The analysis is focused on the agrarian origins of the People's Party, and the division it postulated between the people and the exploitive moneyed elite. Kazin (1995) brings the discussion up to Nixon and Reagan. For a discussion of Donald Trump and Bernie Sanders see Macawley (2019).

2. The same authors offer an analysis of the issues confronting the attempt at definition of corruption (Bull and Newell, 1997). See also their useful explanation of the 
role of European scandals in propelling the realization that new understandings are required in Bull and Newell (2015).

3. Podemos is one example, and another is President Obama. However, what he had in mind was not the political but the economic meaning of populism. See Roberts (2016).

4. Between 1990 and 2010, Rovira Kaltwasser et al. (2017) counted more than 1200 academic books in English alone (p. 10). This preceded the wave triggered by Brexit and the election of Trump. The examination by Rooduijn (2019) of the number of mentions of the terms in the New York Times is telling: in 2015, 671 times; a year later, 1399; and, in 2017, 2537. As for the number of articles featuring "populism" or "populist" in their title, Rooduijn counted 76 in 2010, 155 in 2015, 208 in 2016 and 382 in 2017.

5. For a discussion of the academic use of the term from 1956 onwards to Albertazzi and McDonnell (2008) see Taggart and Van Kessel (2009).

6. Bale et al. (2011) offer an examination of the vernacular use of "populism" and "populist" in the British "broadsheet" newspapers between October and December 2007 and July and September 2008. Their conclusion was that the terms were not central to the content of the articles in which they appeared, that the concept stretches to cover actors from a variety of continents and policy areas, that they were used by both Left and Right as pejoratives by which to define the "other side" and hence what was named "populist" could be contradictory, and that, as a consequence of all the above, the terms were used almost randomly.

7. De la Torre and Mazzoleni agree with Ochoa Espejo (2017: 618-619) that Mudde's definition makes strong normative claims on democracy and the proper role of people within it.

8. The strategy itself was suggested by Giovani Sartori in 1970 and applied as a solution for the definition of populism by Kurt Weyland. Both contributions were noted by Mudde and Kaltswasser (2013: 149, 153).

9. Among others see Cas Mudde (2007) and (2017), and Mudde and Rovira Kaltwasser $(2013,2017,2018)$. Efforts to arrive at a minimal definition that would hold true for populist manifestations regardless of differences were made by others . For instance. Hawkins's (2009: 1042) definition of populism as "a Manichean discourse that identifies Good with the unified will of the people and Evil with a conspiring elite", Pappas's (2014b: 2-4), "democratic illiberalism" (made famous by its adoption by Viktor Orbán), Jensen (2011: 82) proposed "any sustained, large-scale political project that mobilizes ordinary marginalized social sectors into publicly visible and contentious political action, while articulating anti-elite, nationalist rhetoric that valorizes ordinary people", while Mansbridge and Macedo (2019) suggest limiting the core element to "the people in moral battle against the elites".

10. The difference, according to Freeden, lies in that, unlike nationalism, environmentalism or feminism, populism does not harbor positive drives and has no aspirational or potential to become full. It has "no outward pointing sockets that enable additional and systematic plug-ins to be attached ... the populist core is all there is" (Freeden, 2017: 3).

11. For an earlier discussion of the concept of homogeneity of the people see, among others, Canovan (1999). A point she makes is that homogeneity figures in three senses that in practice tend to blend: the appeal to the unity of the people against those who divide it, to "our people," which often has ethnic echoes, and the mobilization of "the common man" against the privileged, highly educated, 
cosmopolitan elite. Each of these (and the entire mixture) is characterized by an inherent tension between the call for unity and the stand against those who threaten to fragment the people.

12. To avoid the confusion, Gagnon et al. (2018) suggest the enumeration of the cleavages among which populism could move. This would allow for nuanced distinction along several dimensions: authoritarian and democratic; market fundamentalists and supporters of economic redistribution; exclusionary and inclusionary, antipluralist and pluralist; xenophobic and cosmopolitan; electoral and participatory; and nostalgic and aspirational (ibid.: vii).

13. Among these one should include Mudde and Rovira Kaltwasser (2013). A version of the article was published earlier (2011). The article compares the populism of Haider and Le Pen to that of Chavez and Morales. The Latin American brand has a socioeconomic dimension while the European one has primarily a sociocultural one . This may be explained by the different socioeconomic conditions in the two parts of the world: Europe had reached a level of development where post-material politics are as, or more, important socioeconomic issues, whereas Latin America had not reached yet this "silent revolution". However, the minimal definition allows one to view the two types as subtypes of the same phenomenon.

14. E.g. Albertazzi and McDonnell (2008). Their definition is "an ideology which pits a virtuous and homogeneous people against a set of elites and dangerous 'others' who are together depicted as depriving (or attempting to deprive) the sovereign people of their rights, values, prosperity, identity and voice" (p. 3).

15. As against the clientilistic systems in Southern Europe and Latin America, the USA and Western Europe present programmatic party systems, where parties provide policy programs utilizing universalist criteria. Whereas the former are likely to produce opportunities for corruption and more radical populism, the latter are prone to relatively minor representational failures that occur when parties fail to adapt to changing voter demands. The governance is stronger and policy crises are shorter-lived and complaints about elite conspiracies are concentrated among constituencies and parties. Populists that come to power are more likely to be constrained by institutions (Hawkins et al., 2016: 103) and reflect a temporary disconnect between traditional parties and their constituents rather than widespread outrage at a political system that has routinely failed to satisfy basic standards of governance (ibid.).

16. A few cases may illustrate. One is of historical figures and movements for whom the title "populism" is problematic, e.g. Gamal Abdel Nasser (Nedelcu, 2014). Specific forms of elite-led movements were likewise defined as populist, as in Nigeria where the quest for Northern hegemony over the Christian elites of the South resulted in a "political movement that is nourished by and draws social and cultural legitimacy from appeals to a religious ideology that excites the passion of ... the population" (Kperogi, 2020: 30). The same may be said of the more general identification of authoritarian, popularly elected leaders within the category. Crewe and Sanders (2020: 3) define authoritarian populism as a two-pronged phenomenon. It consists of leaders elected on simplistic, nationalist platforms and a mindset among their supporters that "embraces resentment of immigrants and immigration, cynicism about human rights, support for robust foreign policies, ideological sympathy for the market and rolling back of the state." Finally, there are cases where "populism" is determined on the bases of popularity and one or other traits associated with the "brand" but usually without specification. A random illustration is Paulina Hanson and her party in Australia. It was pointed 
out (Goot, 2003) that they could be identified as extreme Right, extreme Left, or Center. Clearly, the identification of nativism as the sole hallmark of populism is insufficient. Rooduijn (2019: 365-366) regards this as a result of the identification of populism with Trump, Le Pen, or Geert Wilders. However, Syriza or Podemos too are populist parties, and the assumption is that less educated publics that are often associated with populism do not necessarily vote for the anti-otherness they offer (Rooduijn, 2017: 351-368).

17. The other differences are largely corollaries of this increasing agreement. These include the emphasis on the measurement of populism, the focus on actors other than politicians and parties, the effort of communication experts to ascertain the extent to which populist messages in the media shape public opinion, and, following the rise to power of populist parties and leaders, to what extent populists are able to actually deliver on their electoral promises (Roodujin. 2019: 363-365).

18. For what the varieties of populism discussed by Rode and Revuelta mean in the "real world" of commerce within and between countries see Devinney and Hartwell (2020).

19. An interesting example was offered by Mark Warren (2001: 297) about the 2000 presidential campaign in the USA. The argument pushed by Bush "shade[d] into the charge that 'government is not to be trusted because it is corrupt'. In turn, this reflects a shift away from an emphasis on the democratic choice between party political platforms over competing visions towards an anti-democratic form of populism."

20. The reference to Müller is made simply because he elaborated in somewhat greater length. Versions of the point were raised both earlier and later. Thus, Ostiguy (2009: 91) in the context of the differentiation between High and Low ways of relating to people - accents, level of language, gestures, ways of dressing etc. - that allow the identification of a person as "one of us." Corruption, in the sense of "the readiness to 'get dirty' for the people is a central discursive feature of many populisms." In a similar vein, Norris and Inglehart (2018: 7) argue that, because leaders like Trump rise to power by claiming to govern on behalf of the "real" people, they knock down safeguards on executive power and draw fuzzy lines between the interests of the state and their personal interests - "along with that of their family and cronies." A similar pattern in reverse was noted by Sierakowski (2019), who points to the growing acceptance, even among supporters of anti-populist parties of rule-breaking and even illegal acts on the part of their chosen political representatives. More and more voters conclude that populists must be beaten at their own game, and opposition parties are faced with a choice between upholding their ethical standards and saving liberal democracy.

\section{REFERENCES}

Agerberg, Mattias (2017), "Failed Expectations: Quality of Government and Support for Populist Parties in Europe", European Journal of Political Research 56 (3), pp. 578-600.

Albertazzi, Danielle and Ducan McDonnell (2015), Populists in Power (London: Routledge).

Albertazzi, Danielle and Ducan McDonnell (2008), "Introduction: The Sceptre and the Spectre", in Danielle Albertazzi and Ducan McDonnell, Twenty-First Century 
Populism: The Spectre of Western European Democracy (Basingstoke, UK: Palgrave Macmillan), pp. 1-11.

Allcock, J. B. (1971), “Populism”: A Brief Biography”, Sociology 5 (3), pp. 371-387.

Bale, Tim, Stijn Van Kessel, and Paul Taggart (2011), "Thrown Around With Abandon? Popular Understandings of Populism as Conveyed by the Print Media: A UK Case Study", Acta Politica 46 (3), pp. 111-131.

Berlin, Isaiah, et al. (1968), "To Define Populism”, Government and Opposition 3 (2), pp. 137-179.

Boatright, Robert G. (2020), "Populist Corruption Talk, and Some Alternatives", in Majia Nadesan and Amit Ron (eds.), Mapping Populism: A Guide to Understanding and Studying Populism (New York: Routledge), pp. 176-184.

Boatright, Robert G. and Molly Brigid McGrath (2020), "Corruption, Populism, and Sloth", in Mark C. Navin and Richard Nunan (eds.), Democracy, Populism, and Truth (Cham, Switzerland: Springer Nature), pp. 47-59.

Bonikowski, Bart and Noam Gidron (2016), "Multiple Traditions in Populism Research: Towards a Theoretical Synthesis", Comparative Politics Newsletter 26 (2), pp. 7-14. Available at newsletter_fall2016.pdf (mattgolder.com) (accessed December 10, 2019).

Buchan, Bruce and Lisa Hill (2014), An Intellectual History of Political Corruption (New York: Palgrave Macmillan).

Bull, Martin and James L. Newell (2015), "Political Corruption in Europe", in José M. Magone (ed.), Routledge Handbook of European Politics (New York: Routledge), pp. 669-685.

Bull, Martin and James L. Newell (2003), "Introduction", in Martin Bull and James Newell (eds.), Corruption In Contemporary Politics (New York: Palgrave Macmillan, 2003).

Bull, Martin and James L. Newell (1997), "New Avenues in the Study of Political Corruption", Crime, Law and Social Change 27 (3-4), pp. 169-183.

Burcham, Manuhuia (2012), "Rule by National Reason: Late Medieval and Early Renaissance Conceptions of Political Corruption", in Manuhuia Barcham, Barry Hindess, and Peter Larmour (eds.), Corruption: Expanding the Focus (Canberra: Australian National University), pp. 53-72.

Canovan, Margaret (2004), "Populism for Political Theorists?", Journal of Political Ideologies 9 (3), pp. 241-251.

Canovan, Margaret (2002), "Taking Politics to the People: Populism as the Ideology of Democracy", in Yves Mény and Yves Surel (eds.) Democracies and the Populist Challenge (London: Palgrave Macmillan), pp. 25-48.

Canovan, Margaret (1999), "Trust the People! Populism and the Two Faces of Democracy", Political Studies 47 (1), pp. 2-16.

Canovan, Margaret (1981), Populism (New York: Harcourt Brace Jovanovich).

Clapham, Christopher (1985), Third World Politics: An Introduction (Madison, MI: University of Minnesota Press).

Crewe, Ivor and David Sanders (2020), "Introduction", in Ivor Crewe and David Sanders (eds.), Authoritarian Populism and Liberal Democracy (Cham, Switzerland: Springer International), pp. 1-12.

Curini, Luigi (2018), Corruption, Ideology, and Populism: The Rise of Valence Political Campaigning (Cham, Switzerland: Springer International).

Dahlberg, Stephen, Jonas Linde, and Soren Holmberg (2013), "Dissatisfied Democrats: A Matter of Representation or Performance", Working Paper Series 2013: 8 QoG, The Quality of Government Institute (Goteborg Sweden: University of Goteborg). 
Deiwiks, Christa (2009), "Populism", Living Reviews in Democracy, Centre for Comparative and International Studies ETH Zurich and University of Zurich. Available at http://www.livingreviews.org/lrd-2009-3 (accessed February 12, 2020).

de la Torre, Carlos (2018), "Global Populism: Histories, Trajectories, Problems, and Challenges", in Carlos de la Tore (ed.), Routledge Handbook of Global Populism (London: Routledge), pp. 2-27.

de la Torre, Carlos and Oscar Mazzoleni (2019), "Do We need a Minimum Definition of Populism? An Appraisal of Mudde's Conceptualization”, Populism 2 (1), pp. 79-95.

Devinney, Timothy and Christopher Hartwell (2020), "Varieties of Populism", Journal of Global Strategy 10 (1), pp. 32-66.

Fieschi, Catherina and Paul Heywood (2004), "Trust Cynicism and Populist Anti-Politics", Journal of Political Ideologies 9 (3), pp. 289-309.

Fogel, Benjamin (2018), "Against 'Anti-Corruption"”, The Jacobin. Available at https://Jacobinnmag.com/2018/10/corruption-bolsonaro-pt-populism-democrcary (accessed January 10, 2020).

Fraser, Nancy (2017), "From Progressive Neoliberalism to Trump - and Beyond", American Affairs I (4), pp. 46-64.

Freeden, Michael (2017), "After Brexit Referendum: Revisiting Populism as an Ideology", Journal of Political Ideologies 22 (3), pp. 1-11.

Freeden, Michael (1998), "Is Nationalism a Distinct Ideology?", Political Studies 46 (4), pp. 748-765.

Gagnon, Jean-Paul, et al. (2018), "Editorial: What is Populism? Who is the Populist?", Democratic Theory 5 (2), pp. v-xxvi.

Gidron, Noam and Bart Bonikowski (2014), "Varieties of Populism: Literature Review and Research Agenda". Weatherhead Center for International Affairs (13-0004). Available at https://ssrn.com./abstract=2459387 (accessed May 15, 2020).

Goot, Murray (2003), "Pauline Hanson's One Nation: Extreme Right, Center, or Extreme Left", Labour History (89), pp. 101-119.

Green, Donald, Bradley Palmquist, and Eric Schickler (2002), Partisan Hearts and Minds: Political Parties and the Social Identity of Voters (New Haven, CT: Yale University Press).

Hacker, Jacob S. and Paul Pierson (2020), Let Them Eat Sweets: How the Right Rules in an Age of Extreme Inequality (New York: Liveright).

Hawkins, Kirk (2009), "Is Chavez Populist? Measuring Populist Discourse in Comparative Perspective", Comparative Political Studies 42 (8), pp. 1040-1067.

Hawkins, Kirk, Rebecca Dudley, and Wen Jie Tan (2016), "Made in the USA: Populism Beyond Europe", in Alberto Martinelli (ed.), Beyond Trump: Populism on the Rise (Milano: ISPI), pp. 93-110.

Heidenheimer, Arnold (1989), "Perceptions on the Perception of Corruption", in Arnold Heidenheimer, Michael Johnston, and Victor LeVine (eds.), Political Corruption: A Handbook (New Brunswick: Transaction), pp. 149-164.

Heywood, Paul, Veronique Pujas, and Martin Rhodes (2002), "Political Corruption, Democracy and Governance in Western Europe", in Paul Heywood, Erik Ones, and Martin Rhodes (eds.), Developments in West European Politics, Vol 2 (Basingstoke: Palgrave 2002), pp. 184-200.

Hill, Lisa (2013), "Conceptions of Political Corruption in Ancient Athens and Rome", History of Political Thought 34 (4), pp. 565-587.

Hindess, Barry (2012), "Introduction: How Should we Think About Corruption", in Manuhuia Burcham, Barry Hindess, and Peter Larmour (eds.), Corruption: Expanding the Focus (Canberra: Australian National University), pp. 1-24. 
Hofstadter, Richard (1969), "North America", in Ernest Gellner and Ghita Ionesco (eds.), Populism: Its Meanings and National Characteristics (London: Weidenfeld and Nicolson), pp. 9-27.

Houven, Thomas (2011), "The Non-European Roots of the Concept of Populism", Working paper 120 (Brighton: University of Sussex).

Huntington, Samuel (1968/1989), "Modernization and Corruption", in Arnold Heidenheimer, Michael Johnston, and Victor LeVine (eds.), Political Corruption: A Handbook (New Brunswick, NJ: Transaction), pp. 377-388.

Ionescu, Ghita and Ernest Gellner (eds.) (1969), Populism: Its Meaning and National Characteristics (London: Weidenfeld and Nicolson).

Jensen, Robert S. (2011), "Populist Mobilization: A New Theoretical Approach to Populism", Sociological Theory 29 (2), pp. 75-96.

Kaufmann, Daniel and Pedro C. Vicente (2011), "Legal Corruption”, Economics and Politics 23 (2), pp. 195-219.

Kazin, Michael (1995), The Populist Persuasion: An American History (Ithaca, NY: Cornell University Press).

Kossow, Niklas (2019), "Populism and Corruption", Transparency International Anti-Corruption Help Desk, January 14. Available at tihelpdesk@transparency.org (accessed August 1, 2019).

Kperogi, Farooq, A. (2020), "Sharia or Death: The Mass Mediated Hegemonic Rhetoric of Theocratic Populism in Nigeria's Moslim North", World Complexity Science Academy Journal I (1), pp. 27-44.

Krastev, Ivan and Stephen Holmes (2020), The Light that Failed: The Reckoning (London: Pegasus).

Krastev, Ivan and Stephen Holmes (2019), "Western Liberalism Failed Post-Communist Eastern Europe", Guardian, October 24. Available at https://www.theguardian .com/world/2019/oct/24/western-liberalism-failed-post-communist-eastern-europe (accessed March 2, 2020).

Krastev, Ivan and Stephen Holmes (2018), "Explaining Eastern Europe: Imitation and its Discontents", Journal of Democracy 29 (3), pp. 117-128.

Kriesi, Hanspeter (2014), "The Populist Challenge", West European Politics 37 (2), pp. 361-378.

Kroeze, Ronald (2016), "The Rediscovery of Corruption in Western Democracies", in Jonathan Mendilow and Ilan Peleg (eds.), Corruption and Government Legitimacy: A Twenty-First-Century Perspective (Lanham, MD: Lexington), pp. 21-40.

Laclau, Ernesto (2005), “Populism: What's In the Name?”, in Francisco Panizza (ed.), Populism and the Mirror of Democracy (London: Verso), pp. 32-49.

Lind, Jonas (2012), "Why Feed the Hand that Bites You? Perceptions of Procedural Fairness and Political Support in Post-Communist Democracies", European Journal of Political Research 5 (2), pp. 410-434.

Macawley, Marcia (2019), "Bernie and the Donald: A Comparison of Left and Right-wing Populist Discourse", in Marcia Macawley (ed.), Populist Discourse: International Perspectives (London: Palgrave Macmillan, 2019), pp. 165-195.

Mansbridge, Jane and Stephen Macedo (2019), "Populism and Democratic Theory", American Review of Law and Social Science 15, pp. 54-77.

Mellman, Aryeh and Norman Eisen (2020), "Addressing the Other COVID Crisis: Corruption”, Brookings Governance Weekly (July 22). Available at GSNewsletter@, brookings.edu (accessed July 23, 2020).

Mendilow, Jonathan (2018), "Digital Gated Communities and the Future of Political Finance", in Jonathan Mendilow and Éric Phélippeau (eds.), Handbook of Political 
Party Funding (Cheltenham, UK and Northampton, MA, USA: Edward Elgar Publishing), pp. 141-156.

Mendilow, Jonathan (2014), "Edmund Burke's Concept of Corruption and Beyond", in Jonathan Mendilow and Ilan Peleg (eds.), Corruption in the Contemporary World: Theory, Practice, and Hotspots (Lanham. MD: Lexington), pp. 1-25.

Mendilow, Jonathan and Ilan Peleg (eds.) (2014), Corruption in the Contemporary World: Theory, Practice, and Hotspots (Lanham, MD: Lexington).

Mendilow, Jonathan and Éric Phélippeau (2019), "Introduction: Political Corruption in a World in Transition", in Jonathan Mendilow and Éric Phélippeau (eds.), Political Corruption in a World in Transition (Wilmington, DE: Vernon), pp. 1-16.

Mény, Yves and Martin Rhodes (1997), "Illicit Governance: Corruption Scandal and Fraud", in Martin Rhodes, Paul Heywood, and Vincent Wright (eds.), Developments in West European Politics (London: Palgrave), pp. 95-113.

Millhiser, Ilan (2019), "The Four Possible Crimes in the Trump-Ukraine Whistleblower Scandal Explained", Vox, September 27.

Moffitt, Benjamin and Simon Tormey (2014), "Rethinking Populism: Politics, Mediatisation and Political Style", Political Studies 62 (2), pp. 381-397.

Mouffe, Chantal (2018), For a Left Populism (New York: Verso).

Mudde, Cas (2017), "Populism: An Ideational Approach", in Cristobal Rovira Kaltwasser, Paul Taggart, Paulina Ochoa Espejo, and Pierre Ostiguy (eds.), The Oxford Handbook of Populism (Oxford: Oxford University Press), pp. 27-47.

Mudde, Cas (2007), Populist Radical Right Parties in Europe (Cambridge: Cambridge University Press).

Mudde, Cas (2004), "The Populist Zeitgeist", Government and Opposition 39 (3), pp. 541-563.

Mudde, Cas and Cristobal Rovira Kaltwasser (2018), "Studying Populism in Comparative Perspective: Reflections on the Contemporary and Future Research Agenda", Comparative Political Studies 51 (13), pp. 1667-1693.

Mudde, Cas and Cristobal Rovira Kaltwasser (2017), Populism: A Very Short Introduction (New York: Oxford University Press).

Mudde, Cas and Cristobal Rovira Kaltwasser (2013), "Exclusionary vs. Inclusionary Populism: Comparing Contemporary Europe and Latin America", Government and Opposition 48 (2), pp. 147-174.

Müller, Jan-Werner (2019), "False Flags: The Myth of Nationalist Resurgence", Foreign Affairs 98 (2), pp. 35-41.

Müller, Jan-Werner (2016), What is Populism? (Philadelphia: University of Pennsylvania Press).

Müller, Jan-Werner (2015), “Parsing Populism”, Juncture 22 (2), pp. 80-89.

Muro, Diego (2017), "Let the People Rule! Definitions and Theories of Populism", in Eckart Woertz (ed.), Populism in Europe from Symptom to Alternative? CIDOB report 01, 2017 (Barcelona: Center for International Affairs), pp. 9-15.

Nedelcu, Christina (2014), "The Metamorphosis of Populism in the Arab World: Gamal Abdel Nasser", South-East European Journal of Political Science II (1), pp. 273-298.

Norris, Pippa and Ronald Inglehart (2018), Cultural Backlash: Trump, Brexit, and the Rise of Authoritarian Populism (New York: Cambridge University Press).

Nye, Joseph S. (1967), "Corruption and Political Development: A Cost-Benefit Analysis”, The American Political Science Review 61 (2), pp. 417-427. 
Ochoa Espejo, Paulina (2017), "Populism and the Idea of the People", in Cristobal Rovira Kaltwasser, Paul Taggart, Paulina Ochoa Espejo, and Pierre Ostiguy, (eds.), The Oxford Handbook of Populism (Oxford: Oxford University Press), pp. 607-628.

O'Connell, Jonathan and Aaron Gregg (2020), "SBA Exempted Lawmakers, Federal Officials from Ethic Ruses in 660 Billion Loan Program", The Washington Post, June 26. Available at https://Washingtonpost.com/business /2020/06/26/ sba-exempted-lawmakers-federal-officials-ethics-rules-660-billion-loan-program (accessed July 15, 2020).

Ostiguy, Pierre (2017), "Populism: A Socio-cultural Approach", in Cristobal Rovira Kaltwasser, Paul Taggart, Paulina Ochoa Espejo, and Pierre Ostiguy (eds.), The Oxford Handbook of Populism (Oxford: Oxford University Press), pp. 73-97.

Ostiguy, Pierre (2009), "The High-Low Political Divide: Rethinking Populism and Anti-Populism". Committee on Concepts and Methods, Working Paper series 35. Available at http://www.concepts-methods.org/Files/workingPaper/PC\%2035 \%20Ostigug.pdf (accessed March 2, 2020).

Ostiguy, Pierre and Kenneth M. Roberts (2016), "Putting Trump in Comparative Perspective: Populism and the Politization of the Sociocultural Low", Journal of World Affairs 23 (1), pp. 25-50.

Page, Matthew (2018), "A New Taxonomy For Corruption in Nigeria", Carnegie Endowment for International Peace. Available at https:/carnegieendowment.org/ files/CP_338_Page_Nigeria_FINAL.pdf. (accessed January 5, 2020).

Panizza, Francisco (2005), Populism and the Mirror of Democracy (London: Verso).

Pappas, Takis (2014), Populism and Crisis Politics in Greece (New York: Palgrave).

Pappas, Takis (2014b), "Populist Democracies: Post-Authoritarian Greece and Post-Communist Hungary”, Government and Opposition 49 (1), pp. 1-23.

Pauwels, Teun (2011), "Measuring Populism: A Quantitative Test Analysis of Party Literature in Belgium", Journal of Elections, Public Opinion and Parties 21 (1), pp. 97-119.

Peleg, Ilan and Jonathan Mendilow (2014), "Corruption in the Arab Spring: Comparing the Pre-and Post-Spring Situation", in Jonathan Mendilow and Ilan Peleg (eds.), Corruption in the Contemporary World: Theory, Practice, and Hotspots (Lanham, MD: Lexington), pp. 99-115.

Pierson, Paul (2017), “American Hybrid: Donald Trump and the Strange Merger of Populism and Plutocracy", The British Journal of Sociology 68 (s1), pp. S105-S119.

Pitcher, Anne, Mary Moran, and Michael Johnston (2009), "Rethinking Patrimonialism and Neo Patrimonialism in Africa", African Studies Review 1 (1), pp. 126-156.

Pujas, Veronique and Martin Rhodes (1999), "Party Finance and Political Scandal in Italy, Spain and France”, West European Politics 22 (3), pp. 41-63.

Rensmann, Lars (2017), "The Noisy Counter-Revolution: Understanding the Cultural Conditions and Dynamics of Populist Politics in Europe and the Digital Age", Politics and Governance 5 (4), pp. 123-135.

Roberts, Kenneth M. (2016), "Populism as Epitaph and Identity: The Use and Misuse of a Contested Concept", Comparative Politics Newsletter 26 (2), pp. 69-72.

Rode, M. and J. Revuelta (2014), "The Wild Bunch! An Empirical Note on Populism and Economic Institutions", Economics of Governance 16 (1), pp. 73-96.

Rodrik, Dani (2018), "Populism and the Economics of Globalization", Journal of International Business Policy I (1-2), pp. 12-33.

Rooduijn, Mathijs (2019), "State of the Field: How to Study Populism and Adjacent Topics? A Plea for Both More and Less Focus", European Journal of Political Research 58 (1), pp. 362-372. 
Rooduijn, Mathijs (2017), "What Unites the Voter Bases of Populist Parties? Comparing the Electorates of 15 Populist Parties", European Political Science Review 10 (3), pp. 351-368.

Rooduijn, Mathijs (2014), "The Nucleus of Populism: In Search of the Lowest Common Denominator", Government and Opposition 49 (4), pp. 572-598.

Rose-Ackerman, Susan and Bonnie J. Palifka (2016), Corruption and Government: Causes, Consequences and Reform (New York: Cambridge University Press).

Rovira Kaltwasser, Cristobal, Paul Taggart, Paulina Ochoa Espejo, and Pierre Ostiguy (2017), "Populism: An Overview of the Concept and the State of the Art", in Cristobal Rovira Kaltwasser, Paul Taggart, Paulina Ochoa Espejo, and Pierre Ostiguy (eds.), Handbook of Populism (Oxford: Oxford University Press), pp. 1-24.

Sierakowski, Slawomir (2019), "Mainstreaming Corruption: How Populism Erodes Moral Standards", Balkan Insight, September 27. Available at https://balkaninsight .com/2019/09/27/mainstreaming-corruption-how-populism-erodes-moral-standards trashed/ (accessed January 4, 2020).

Skocpol, Theda (1982), "Bringing the State Back In", Items 36 (no.1-2), pp. 1-8.

Smith, David and Eric Hanley (2018), "The Anger Games: Who Voted for Donald Trump in the 2016 Election, and Why?", Critical Sociology 44 (2), pp. 195-212.

Stanley, Ben (2008), "The Thin Ideology of Populism”, Journal of Political Ideologies 13 (1), pp. 95-110.

Taggart, Paul and Stijn Van Kessel (2009), “The Problems of Populism”, paper presented at the Dutch-Flemish conference, Het Politicologenetmall, May 28-29.

Theobald, Robin and Robert Williams (2005), "Combating Corruption in Botswana: Regional Role Model or Deviant Case?”, in Alan Doig and Robin Theobald (eds.), Corruption and Democratization (London: Frank Cass), pp. 117-134.

Urbinati, Nadia (2019), "The Phenomenology of Politics as Factionalism", Constellations 26 (3), pp. 408-417.

Urbinati, Nadia (2017), "Antiestablishment and the Substitution of the Whole with One of its Parts", in Carlos de la Torre (ed.), The Routledge Handbook of Global Populism (London: Routledge), pp. 77-97.

Urbinati, Nadia (1998), "Democracy and Populism”, Constellations 5 (1), pp. 110-124.

Urpo, Kavala and Emilia Palonen (2018), "Populism on the Loose: Seminal Reflections on the Condition of Differentiality", in Kavala Urpo, Emilia Palonen, Maria Ruotsolainen, and Tuija Savesma (eds.), Populism on the Loose (Jyvaskysuja, Finland: Jyvaskylan Yliapisto), pp. 13-26.

Vitton, David (2017), "Re-Conceptualizing Populism: Bringing a Multifaceted Concept within Stricter Borders", Revista Espanola de Ciencia Politica 44, pp. 43-65.

Vogl, Frank (2020), "Trump and Corruption: Who Cares in the Time of COVID? The Art of Undermining, or: How Easily U.S. President Donald Trump Gets Away with Corruption", The Globalist, July 15. Available at www.theglobalist.com (accessed July 15,2020$)$.

Warren, Mark (2006), "Political Corruption as Duplicitous Exclusion”, PS 39 (4), pp. 803-807.

Warren, Mark (2004), "What Does Corruption Mean in Democracy?", American Journal of Political Science 48 (2), p. 328.

Warren, Mark (2001), "Trust in Democratic Institutions", paper prepared for the EURESCO Conference on Social Capital: Interdisciplinary Perspectives, University of Exeter, September 15-20, pp. 1, 295-301. 
Watt, David, Rachel Flanary, and Robin Theobald (2005), "Democratization or the Democratization of Corruption? The Case of Uganda", in Alan Doig and Robin Theobald (eds.), Corruption and Democratization (London: Frank Cass), pp. 37-64.

Weyland, Kurt (2017), "Populism: A Political Strategy Approach", in Cristobal Rovira Kaltwasser, Paul Taggart, Paulin Ochoa Espejo, and Pierre Ostiguy (eds.), The Oxford Handbook of Populism (Oxford: Oxford University Press), pp. 48-72.

Weyland, Kurt (2001), "Clarifying a Contested Concept: Populism in the Study of Latin American Politics", Comparative Politics 34 (1), pp. 1-22.

Wils, Paul (1969), "A Syndrome, Not a Doctrine: Some Elementary Theses on Populism", in Ghita Ionescu and Ernest Gellner (eds.), Populism: Its Meaning and National Characteristics (London: Weidenfeld and Nicolson), pp. 166-179.

Woods, Dwayne (2014), "The Many Faces of Populism: Diverse But Not Disparate", Current Perspectives. Research in Political Sociology 22, pp. 1-25. Available at https://doi.org/10.1108/So895-99352014000002201 (accessed July 10, 2020).

World Bank Poverty Reduction and Economic Management Network (1997), Helping Countries Combat Corruption: The Role of the World Bank (Washington, DC: World Bank). Available at http://worldbank.org/publicsector/anticorruption/corruption/ corruption.pdf (accessed July 10, 2020). 